Article

\title{
Palladium nanoparticles in cross-linked polyaniline as highly efficient catalysts for Suzuki-Miyaura reactions
}

\author{
Haipeng Fan, Zhengliang Qi, Dejun Sui, Fei Mao, Rizhi Chen, Jun Huang* \\ State Key Laboratory of Materials-Oriented Chemical Engineering, College of Chemical Engineering, Nanjing Tech University, Nanjing 210009, Jiangsu, \\ China
}

A R T I C L E I N F

Article history:

Received 29 November 2016

Accepted 27 December 2016

Published 5 March 2017

\section{Keywords:}

Palladium

Heterogeneous catalyst

Polyaniline

Suzuki-Miyaura coupling reactions

Biphenyls

\begin{abstract}
A B S T R A C T
Palladium nanoparticles supported on cross-linked polyaniline with bulky phosphorus ligands were developed. These catalysts showed high efficiency in the Suzuki-Miyaura reaction of aryl chlorides and bromides with phenylboronic acids. Aryl chlorides and bromides with functional groups, such as $\mathrm{CN}, \mathrm{MeO}, \mathrm{CHO}, \mathrm{MeCO}$ and $\mathrm{NO}_{2}$, were converted to the corresponding biphenyls in high yields with catalyst loading. Additionally, the catalysts combined high activity with good reusability; they could be used at least five times for the Suzuki-Miyaura coupling reaction.
\end{abstract}

(C) 2017, Dalian Institute of Chemical Physics, Chinese Academy of Sciences. Published by Elsevier B.V. All rights reserved.

\section{Introduction}

The palladium (Pd)-catalysed Suzuki-Miyaura reaction is one of the most powerful protocols used in the synthesis of agrochemicals, pharmaceuticals, natural products and other materials, and has been studied extensively in the past few decades [1-10]. Recently, numerous homogeneous catalysts have been developed, and lots of efficient ligands for the Suzuki-Miyaura reaction have been designed. However, ligands for Pd homogeneous catalysts are usually expensive and complicated to synthesise [11-15]. The recovery of active Pd/ligand catalyst systems is valuable not only for economic reasons but also to avoid product contamination. Thus, much effort has been devoted to designing heterogeneous Pd catalysts, such as Pd supported on metal-organic frameworks, carbon, mesoporous zeolites, metal oxides and polymers, for use in Suzu-
ki-Miyaura coupling reactions [16-24]. However, heterogeneous Pd catalysts are usually not as active as homogeneous $\mathrm{Pd} /$ ligand systems. Although some remarkably active heterogeneous Pd catalysts for the Suzuki-Miyaura cross coupling of aryl bromides with arylboronic acids have been reported, it is still desirable to develop highly active heterogeneous Pd catalysts for the Suzuki-Miyaura reaction of aryl chlorides[25-28]. Because the $\mathrm{C}-\mathrm{Cl}$ bond is stronger than the $\mathrm{C}-\mathrm{Br}$ bond, aryl chlorides are difficult to activate. Despite this, aryl chlorides are attractive substrates in Suzuki-Miyaura reactions because they are inexpensive and widely commercially available, so more active Pd catalysts are required. Few heterogeneous Pd catalysts able to activate aryl chlorides for Suzuki-Miyaura reaction have been reported (for example, turnover number (TON) > 1000 with chloroanisole) [29-34].

Recently, we have developed the C-O and C-CN coupling re-

\footnotetext{
* Corresponding author. Tel: +86-25-83172261; Fax:+86-25-83172261; E-mail: junhuang@njtech.edu.cn

This work was supported by the National Natural Science of Foundation of China (21676140), the fund from the State Key Laboratory of Materials-Oriented Chemical Engineering (ZK201402) and the Project of Priority Academic Program Development (PAPD) of Jiangsu Higher Education Institutions.

DOI: 10.1016/S1872-2067(17)62772-4 | http://www.sciencedirect.com/science/journal/18722067| Chin. J. Catal., Vol. 38, No. 3, March 2017
} 
actions of aryl chlorides and bromides with phenols and $\mathrm{K}_{4} \mathrm{Fe}(\mathrm{CN})_{6}$ using heterogeneous and homogeneous catalyst systems [35-37]. Moreover, Pd nanoparticles formed in situ in ionic solid polymers have been reported as highly active heterogeneous catalysts for the Suzuki-Miyaura reaction; only $10^{-7}$ Pd catalysts were required for the Suzuki-Miyaura reaction of aryl bromides [38]. In addition, heterogeneous catalysts with highly active Pd nanoparticles immobilised in situ have been designed and used in Suzuki-Miyaura reactions; these catalysts can be reused several times without evident deactivation [39]. It was found that electron-rich and bulky phosphorus (P) ligands enhanced the activity of these Pd catalysts. Besides, Pd nanoparticles immobilised in $\mathrm{N}$-containing polymers by Pd-catalysed C-N coupling of tris(4-bromophenyl)amine with piperazine have been applied as catalysts, achieving a TON and turnover frequency (TOF) as high as 250000 and $41666 \mathrm{~h}^{-1}$, respectively, in Suzuki-Miyaura reactions [40]. We are still interested in the development of highly active Pd catalysts for Pd-catalysed cross-coupling reactions.

In homogeneous Pd catalyst systems, good ligands for cross-coupling reactions combine both favourable electronic and steric properties. On the one hand, electron-rich ligands can aid oxidative addition to the Pd center to activate aryl halides. On the other hand, bulky ligands can improve the reductive elimination from the Pd center to form products. Moreover, Pd nanoparticles supported on polyaniline (PAN) have been reported as highly active and reusable catalysts for Suzuki-Miyaura reactions, but the recycling process was not easy [41-44]. Inspired by these advances, have we attempted to combine a PAN support and bulky ligands with Pd nanoparticles to form highly active, reusable Pd catalysts. Pd nanoparticles are encapsulated in situ in cross-linked PAN by Pd-catalysed C-N coupling of tris(4-iodophenyl)amine with $p$-phenylenediamine as highly active catalysts for Suzuki-Miyaura reactions (see Scheme 1). The resulting Pd catalysts exhibit high efficiency for the Suzuki-Miyaura coupling of aryl bromides and chlorides with aryl boronic acids. No Pd leaching is detected in the reaction solution after filtration of the $\mathrm{Pd}$ catalysts, revealing that we attained active, clean Pd catalysts for Suzuki-Miyaura reactions.

\section{Experimental}

\subsection{General methods and reagents}

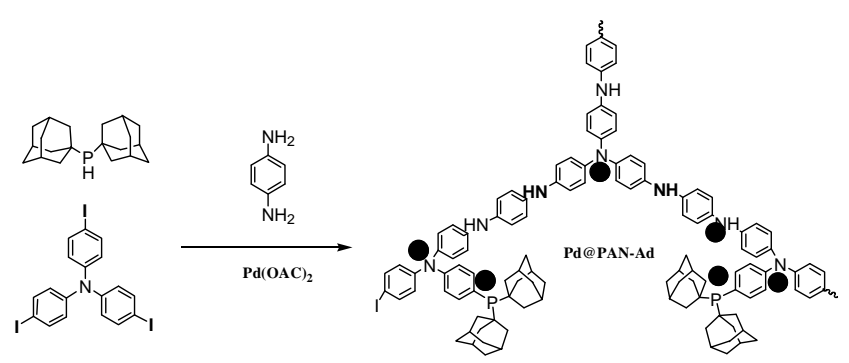

Scheme 1. Synthesis of the palladium nanoparticle/polyaniline/di-1-adamantylphosphine (Pd@PAN-Ad) catalysts.
All chemicals used in this work were purchased from Alfa Aesar, Aladdin Reagent Company and Sigma-Aldrich and used without further purification. ${ }^{1} \mathrm{H}$ NMR spectra were measured with a Bruker AVANCE 400D spectrometer in $\mathrm{CDCl}_{3}$ using tetramethylsilane as an internal reference. Thermogravimetric analysis (TGA) was performed with a STA409 instrument under dry nitrogen at a heating rate of $20{ }^{\circ} \mathrm{C} / \mathrm{min}$. Gas sorption/desorption analysis was performed on a Micromeritics ASAP2010 analyser at $-196{ }^{\circ} \mathrm{C}$ with liquid nitrogen. Samples were pretreated at $140{ }^{\circ} \mathrm{C}$ under vacuum before analysis. The amount of Pd was measured with a Jarrell-Ash 1100 inductively coupled plasma-atomic emission spectrometer (ICP-AES). Transmission electron microscope (TEM) images were captured using a JEOL JEM-2010 (200 kV) TEM and scanning electron microscope (SEM) images were obtained using a Hitachi S-4800 field-emission SEM. Fourier transform infrared (FT-IR) spectra were recorded in the $500-4000 \mathrm{~cm}^{-1}$ region using a Nicolet 360 FT-IR spectrometer with a scan rate of 0.4747 $\mathrm{cm} / \mathrm{s}$. X-ray photoelectron spectroscopy (XPS) was conducted with an ESCALab 220i-XL electron spectrometer from VG Scientific using 300-W Al $K_{\alpha}$ radiation. Binding energies were calibrated using the $\mathrm{C} 1 \mathrm{~s}$ peak at $284.6 \mathrm{eV}$. X-ray diffraction (XRD) patterns were collected on a Bruker D8 Advance powder diffractometer using a $\mathrm{Ni}$-filtered $\mathrm{Cu} K_{\alpha}$ radiation source at $40 \mathrm{kV}$ and $20 \mathrm{~mA}$ from $5^{\circ}$ to $80^{\circ}$ with a scan rate of $0.5^{\circ} / \mathrm{min}$.

\subsection{Preparation of heterogeneous Pd catalysts}

Synthesis of Pd@PAN-Ad-0.5 catalyst: The C-P coupling reaction was conducted according to a reported method with modification [45]. Di-1-adamantylphosphine $\left(\mathrm{HPad}_{2}, 77.2 \mathrm{mg}\right.$, $0.25 \mathrm{mmol}$ ), tris(4-iodophenyl)amine (1.25 mmol, $778.8 \mathrm{mg}$ ),

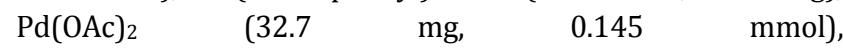
1,1'-bis(diisopropylphosphino)ferrocene (dippf, $6.4 \mathrm{mg}, 0.015$ mmol) and $\mathrm{NaOtBu}(36 \mathrm{mg}, 0.37 \mathrm{mmol}$ ) were added into a 100-mL Schlenk tube containing toluene $(15 \mathrm{~mL})$ under argon. After the Schlenk tube was heated at $100{ }^{\circ} \mathrm{C}$ with stirring for 22 $\mathrm{h}$, the reaction mixture was cooled to room temperature. Then, $p$-phenylenediamine (189.3 mg, $1.75 \mathrm{mmol}$ ), $\mathrm{NaOtBu}(673.0$ $\mathrm{mg}, 7 \mathrm{mmol})$ and toluene $(20 \mathrm{~mL})$ were added to the tube under argon. After heating at $100{ }^{\circ} \mathrm{C}$ with stirring for another $24 \mathrm{~h}$ under argon, the reaction mixture was again cooled to room temperature. The dark blue solid catalyst was obtained via centrifugation, and then washed with water and ethanol three times. The Pd@PAN-Ad-0.5 catalyst was obtained after drying under vacuum for $24 \mathrm{~h}$ at room temperature. The Pd content of the Pd@PAN-Ad-0.5 catalyst measured by ICP-AES was 0.58 wt\%. A Pd@PAN-Cy-0.5 catalyst was prepared similarly using dicyclohexylphosphine instead of di-1-adamantylphosphine. The amount of Pd in the Pd@PAN-Cy-0.5 catalyst was 0.53 $w t \%$.

The catalyst Pd@PAN-Ad-0.2 was prepared similarly to the Pd@PAN-Ad-0.5 catalyst, but 16.3 mg of Pd(OAc) 2 was added instead of $32.7 \mathrm{mg}$. The Pd content in the Pd@PAN-Ad-0.2 catalyst measured by ICP-AES was $0.25 \mathrm{wt} \%$.

\subsection{Typical procedure for Suzuki-Miyaura coupling of aryl}


chlorides with phenylboronic acids using Pd@PAN-Ad-0.5

Aryl chloride (1.0 mmol), phenylboronic acid (1.5 mmol), Pd@PAN-Ad-0.5 catalyst (13.7 mg, 0.075 mol\% Pd), $\mathrm{K}_{2} \mathrm{CO}_{3}$ (280.5 mg, $2.0 \mathrm{mmol}$ ) and $i$-PrOH/water $(2.0 \mathrm{~mL}, 1: 1$ volume ratio) were added to a $20-\mathrm{mL}$ pressure tube under argon. After the tube was heated at $100{ }^{\circ} \mathrm{C}$ for $18 \mathrm{~h}$ with stirring in an oil bath, the reaction mixture was cooled to room temperature. The crude product was purified by column chromatography on silica gel and analysed by ${ }^{1} \mathrm{H}$ NMR spectroscopy to confirm the product.

\subsection{Typical procedure for Suzuki-Miyaura coupling of aryl bromides with phenylboronic acids with Pd@PAN-Ad-0.5}

Aryl bromide (1.0 mmol), phenylboronic acid (1.5 mmol), Pd@PAN-Ad-0.5 catalyst (13.7 mg, 0.075 mol\% Pd), $\mathrm{K}_{2} \mathrm{CO}_{3}$ (280.5 mg, $2.0 \mathrm{mmol})$ and $i$-PrOH/water $(2.0 \mathrm{~mL}, 1: 1$ volume ratio) were added to a $20-\mathrm{mL}$ pressure tube under argon. The tube was put into an oil bath at $100{ }^{\circ} \mathrm{C}$ and stirred for $6 \mathrm{~h}$. After the reaction mixture was cooled to room temperature, the organic layer was extracted with ethyl acetate. The crude product was purified by column chromatography on silica gel.

\subsection{Suzuki-Miyaura coupling of 2-nitrochlorobenzene with 4-chlorophenylboronic acid using Pd@PAN-Ad-0.5}

In this coupling reaction, 2-nitrochlorobenzene $(157.5 \mathrm{mg}$, $1.0 \mathrm{mmol}$ ), 4-chlorophenylboronic acid (188.5 mg, $1.2 \mathrm{mmol}$ ), Pd@PAN-Ad-0.5 (13.7 mg, 0.075 mol\% Pd), $\mathrm{K}_{2} \mathrm{CO}_{3}$ (280.5 mg, $2.0 \mathrm{mmol}$ ) and $i-\mathrm{PrOH} /$ water $(2.0 \mathrm{~mL}, 1: 1$ volume ratio) were added to a $20-\mathrm{mL}$ pressure tube under argon. The tube was put into an oil bath at $100{ }^{\circ} \mathrm{C}$ and stirred for $12 \mathrm{~h}$. After the reaction mixture had cooled to room temperature, the organic layer was extracted with ethyl acetate. The crude product was purified by column chromatography on silica gel.

\subsection{Reusability of the Pd catalyst in the Suzuki-Miyaura cou-} pling of 2-chlorobenzonitrile with 4-methylphenylboronic acid

First, 2-chlorobenzonitrile $(4.0 \mathrm{mmol}, \quad 630.2 \mathrm{mg})$, 4-methylphenylboronic acid $(6.0 \mathrm{mmol}, 811.2 \mathrm{mg})$, Pd@PAN-Ad-0.5 (55.0 mg, 0.075 mol\% Pd), $\mathrm{K}_{2} \mathrm{CO}_{3}$ (1.12 g, 8.0 $\mathrm{mmol}$ ) and $i$-PrOH/water ( $8.0 \mathrm{~mL}, 1: 1$ volume ratio) were added to a Schlenk tube containing a stir bar. The mixture was stirred in a preheated oil bath at $100{ }^{\circ} \mathrm{C}$ for $8 \mathrm{~h}$. The reaction mixture was cooled to room temperature and then hexadecane $(100 \mu \mathrm{L})$ was added as an internal standard. The organic layer was analysed by gas chromatography (GC) to determine the yield. The solid catalyst Pd@PAN-Ad-0.5 was collected by centrifugation and washed with ethyl acetate, water and $i$-PrOH. The recycled Pd@PAN-Ad-0.5 was used again in the same procedure.

\section{Results and discussion}

3.1. Optimisation of the reaction conditions for the Pd-catalysed Suzuki-Miyaura coupling reaction of 4-chloroanisole with phenylboronic acid

Initially, the Pd catalysts were tested in the Suzuki-Miyaura coupling reaction of 4-chloroanisole with phenylboronic acid to optimise conditions. As shown in Table 1, $i$ - $\mathrm{PrOH} / \mathrm{H}_{2} \mathrm{O}$ (1:1 volume ratio) was found to be the best solvent, providing 4-methoxybiphenyl in $42 \%$ yield (Table 1 , entry 1 ). Other solvents gave lower yields than $i-\mathrm{PrOH} / \mathrm{H}_{2} \mathrm{O}$ (Table 1 , entries 2-11). Base optimisation was also performed; $\mathrm{K}_{2} \mathrm{CO}_{3}$ was a suitable base, although $\mathrm{K}_{3} \mathrm{PO}_{4}$ was similarly efficient for the Pd-catalysed Suzuki-Miyaura coupling reactions (Table 1, entries 12-16). When the loading of the $\mathrm{Pd}$ catalyst (Pd@PAN-Ad-0.5) was decreased to $0.075 \mathrm{~mol} \%$ and 0.05 mol\%, 4-methoxybiphenyl was obtained in $99 \%$ and $85 \%$ yield, respectively, with TOF values of 73.3 and $94.4 \mathrm{~h}^{-1}$, respectively (Table 1, entries 17 and18). For comparison, Pd/C, Pd@PAN-Ad-0.2 and Pd@PAN-Cy-0.5 catalysts were also used for the Suzuki-Miyaura coupling reaction of 4-chloroanisole with phenylboronic acid. These catalysts provided

Table 1

Optimisation of the conditions in the Pd-catalysed Suzuki-Miyaura coupling reaction of 4-chloroanisole with phenylboronic acid a.

\begin{tabular}{|c|c|c|c|c|c|c|}
\hline Entry & Base b & Solvent & $\begin{array}{c}\text { Time } \\
\text { (h) }\end{array}$ & $\begin{array}{c}\mathrm{Pd} \\
(\mathrm{mol} \%) \\
\end{array}$ & $\begin{array}{c}\text { Yield }^{\mathrm{f}} \\
(\%) \\
\end{array}$ & $\begin{array}{l}\text { TOF g } \\
\left(\mathrm{h}^{-1}\right) \\
\end{array}$ \\
\hline 1 & $\mathrm{NaOH}$ & $i-\mathrm{PrOH} / \mathrm{H}_{2} \mathrm{O}$ & 10 & 0.15 & 42 & 28.0 \\
\hline 2 & $\mathrm{NaOH}$ & $i$-PrOH & 10 & 0.15 & 5 & 3.4 \\
\hline 3 & $\mathrm{NaOH}$ & $\mathrm{H}_{2} \mathrm{O}$ & 10 & 0.15 & 28 & 18.7 \\
\hline 4 & $\mathrm{NaOH}$ & Toluene $/ \mathrm{H}_{2} \mathrm{O}$ & 10 & 0.15 & 3 & 2.0 \\
\hline 5 & $\mathrm{NaOH}$ & Toluene & 10 & 0.15 & 2 & 1.4 \\
\hline 6 & $\mathrm{NaOH}$ & $\mathrm{DMF} / \mathrm{H}_{2} \mathrm{O}$ & 10 & 0.15 & 4 & 2.7 \\
\hline 7 & $\mathrm{NaOH}$ & DMF & 10 & 0.15 & 5 & 3.4 \\
\hline 8 & $\mathrm{NaOH}$ & 1,4-Dioxane $/ \mathrm{H}_{2} \mathrm{O}$ & 10 & 0.15 & 40 & 26.7 \\
\hline 9 & $\mathrm{NaOH}$ & 1,4-Dioxane & 10 & 0.15 & 34 & 22.7 \\
\hline 10 & $\mathrm{NaOH}$ & Acetonitrile $/ \mathrm{H}_{2} \mathrm{O}$ & 10 & 0.15 & 14 & 9.4 \\
\hline 11 & $\mathrm{NaOH}$ & Acetonitrile & 10 & 0.15 & 8 & 5.4 \\
\hline 12 & $\mathrm{NaOH}$ & $i-\mathrm{PrOH} / \mathrm{H}_{2} \mathrm{O}$ & 18 & 0.15 & 65 & 24.1 \\
\hline 13 & $\mathrm{~K}_{2} \mathrm{CO}_{3}$ & $i-\mathrm{PrOH} / \mathrm{H}_{2} \mathrm{O}$ & 18 & 0.15 & 100 & 37.1 \\
\hline 14 & $\mathrm{~K}_{3} \mathrm{PO}_{4}$ & $i-\mathrm{PrOH} / \mathrm{H}_{2} \mathrm{O}$ & 18 & 0.15 & 97 & 35.9 \\
\hline 15 & $\mathrm{Cs}_{2} \mathrm{CO}_{3}$ & $i-\mathrm{PrOH} / \mathrm{H}_{2} \mathrm{O}$ & 18 & 0.15 & 60 & 22.2 \\
\hline 16 & $\mathrm{Na}_{2} \mathrm{CO}_{3}$ & $i-\mathrm{PrOH} / \mathrm{H}_{2} \mathrm{O}$ & 18 & 0.15 & 72 & 26.7 \\
\hline 17 & $\mathrm{~K}_{2} \mathrm{CO}_{3}$ & $i-\mathrm{PrOH} / \mathrm{H}_{2} \mathrm{O}$ & 18 & 0.075 & 99 & 73.3 \\
\hline 18 & $\mathrm{~K}_{2} \mathrm{CO}_{3}$ & $i-\mathrm{PrOH} / \mathrm{H}_{2} \mathrm{O}$ & 18 & 0.05 & 85 & 94.4 \\
\hline $19 \mathrm{c}$ & $\mathrm{K}_{2} \mathrm{CO}_{3}$ & $i-\mathrm{PrOH} / \mathrm{H}_{2} \mathrm{O}$ & 18 & 0.075 & 9 & 6.7 \\
\hline $20^{d}$ & $\mathrm{~K}_{2} \mathrm{CO}_{3}$ & $i-\mathrm{PrOH} / \mathrm{H}_{2} \mathrm{O}$ & 18 & 0.075 & 88 & 65.2 \\
\hline $21^{\mathrm{e}}$ & $\mathrm{K}_{2} \mathrm{CO}_{3}$ & $i-\mathrm{PrOH} / \mathrm{H}_{2} \mathrm{O}$ & 18 & 0.075 & 23 & 17.0 \\
\hline
\end{tabular}

a Reaction conditions: 4-chloroanisole, $1.0 \mathrm{mmol}$; phenylboronic acid, 1.5 mmol; catalyst Pd@PAN-Ad-0.5 (Pd content 0.58 wt\%); $\mathrm{NaOH},(4.0$ mmol, $160.1 \mathrm{mg}$ ); solvent volume, $2.0 \mathrm{~mL}$; under argon; temperature, $100^{\circ} \mathrm{C}$.

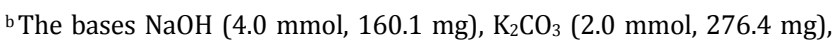
$\mathrm{Cs}_{2} \mathrm{CO}_{3}$ (2.0 mmol, $651.6 \mathrm{mg}$ ), $\mathrm{Na}_{2} \mathrm{CO}_{3}\left(2.0 \mathrm{mmol}, 211.9 \mathrm{mg}\right.$ ), and $\mathrm{K}_{3} \mathrm{PO}_{4}$ (1.3 mmol, $275.9 \mathrm{mg}$ ) were used.

${ }^{c} \mathrm{Pd} / \mathrm{C}$ was used as the catalyst (Pd content $5 \mathrm{wt} \%$ ).

d Pd@PAN-Ad-0.2 was used as the catalyst.

ePd@PAN-Cy-0.5 was used as the catalyst.

f Yields were determined by GC using hexadecane as an internal standard.

g Moles of product per mole of Pd per h. 
4-methoxybiphenyl with lower yield than that obtained using the Pd@PAN-Ad-0.5 catalyst (Table 1, entries 19-21).

\subsection{Pd-catalysed Suzuki-Miyaura coupling reaction of aryl chlorides with phenylboronic acids}

Using the optimised reaction conditions, the application scope of the Pd@PAN-Ad-0.5-catalysed Suzuki-Miyaura reactions of aryl chlorides was studied with phenylboronic acids; the results are listed in Table 2. The Pd@PAN-Ad-0.5 catalyst showed high efficiency for the Suzuki-Miyaura reaction of aryl chlorides with phenylboronic acids, providing the corresponding products in good to excellent yields with quite low Pd catalyst loading (Table 2, entries 1-12). A range of functional groups were well tolerated under the reaction conditions. Aryl chlorides containing $\mathrm{MeCO}, \mathrm{CN}, \mathrm{Me}, \mathrm{MeO}$ and $\mathrm{HCO}$ groups were converted to the corresponding biphenyl products in high yields (Table 2, entries 1-9). Moreover, the Suzuki-Miyaura coupling reactions of chlorobenzene with functional phenylboronic acids also gave the corresponding biphenyl products in high yields (Table 2, entries 10 and 11). Sartanbiphenyl is an important pharmaceutical intermediate for the synthesis of sartan antihypertensive drugs, so the Suzuki-Miyaura coupling reaction of 2-chlorobenzonitrile with 4-methylphenylboronic acid was studied; sartanbiphenyl was obtained quantitatively.

\subsection{Pd-catalysed Suzuki-Miyaura coupling reactions of aryl bromides with phenylboronic acids}

Because aryl bromides are widely available, we also studied the Suzuki-Miyaura reactions of aryl bromides with phenylboronic acids; the results are presented in Table 3. The Suzuki-Miyaura reaction of aryl bromides containing functional groups, such as 4-MeO, 4-HCO, 4-MeCO, 4- $\mathrm{NO}_{2}$, 4-Me, 4-CN, 2-CN, 2- $\mathrm{NO}_{2}, 2-\mathrm{Me}, 2-\mathrm{MeO}$ and 4-tert-Bu, gave the correspond-

Table 2

Suzuki-Miyaura coupling reactions of aryl chlorides and phenylboronic acids ${ }^{\text {a }}$.

\begin{tabular}{|c|c|c|c|}
\hline Entry & $\mathrm{R}_{1}$ & $\mathrm{R}_{2}$ & Yield c $(\%)^{\circ}$ \\
\hline 1 & 4-MeCO & $\mathrm{H}$ & 99 \\
\hline 2 & $4-\mathrm{CN}$ & $\mathrm{H}$ & 99 \\
\hline 3 & $2-\mathrm{CN}$ & $\mathrm{H}$ & 99 \\
\hline 4 & 4-Me & $\mathrm{H}$ & 99 \\
\hline 5 & 2-Me & $\mathrm{H}$ & 100 \\
\hline 6 & $4-\mathrm{NO}_{2}$ & $\mathrm{H}$ & 99 \\
\hline 7 & $2-\mathrm{NO}_{2}$ & $\mathrm{H}$ & 98 \\
\hline 8 & 2-MeO & $\mathrm{H}$ & 99 \\
\hline 9 & 2-CHO & $\mathrm{H}$ & 98 \\
\hline 10 & $\mathrm{H}$ & 4-Me & 85 \\
\hline 11 & $\mathrm{H}$ & 4-MeO & 82 \\
\hline $12 \mathrm{~b}$ & $2-\mathrm{CN}$ & 4-Me & 99 \\
\hline
\end{tabular}

a Reaction conditions: aryl chlorides, $1.0 \mathrm{mmol}$; phenylboronic acids, 1.5 mmol; $\mathrm{K}_{2} \mathrm{CO}_{3}$, (2.0 mmol, $276.4 \mathrm{mg}$ ); catalyst Pd@PAN-Ad-0.5, (13.7 mg, $0.075 \mathrm{~mol} \% \mathrm{Pd}$ ); $i-\mathrm{PrOH} / \mathrm{H}_{2} \mathrm{O}, 2.0 \mathrm{~mL}$; temperature, $100{ }^{\circ} \mathrm{C}$; time, $18 \mathrm{~h}$; under argon.

b Time, $8 \mathrm{~h}$

cIsolated yield.
Table 3

Suzuki-Miyaura coupling of aryl bromides and phenylboronic acids a.

\begin{tabular}{|c|c|c|c|c|}
\hline Entry & $\mathrm{R}_{1}$ & $\mathrm{R}_{2}$ & Time(h) & Yield ${ }^{\mathrm{b}}(\%)$ \\
\hline 1 & 4-MeO & $\mathrm{H}$ & 6 & 100 \\
\hline 2 & 4-CHO & $\mathrm{H}$ & 6 & 100 \\
\hline 3 & 4-MeCO & $\mathrm{H}$ & 6 & 99 \\
\hline 4 & $4-\mathrm{NO}_{2}$ & $\mathrm{H}$ & 6 & 100 \\
\hline 5 & 4-Me & $\mathrm{H}$ & 6 & 95 \\
\hline 6 & $4-\mathrm{CN}$ & $\mathrm{H}$ & 6 & 100 \\
\hline 7 & $2-\mathrm{CN}$ & $\mathrm{H}$ & 10 & 100 \\
\hline 8 & $2-\mathrm{NO}_{2}$ & $\mathrm{H}$ & 10 & 100 \\
\hline 9 & 2-Me & $\mathrm{H}$ & 10 & 99 \\
\hline 10 & 2-MeO & $\mathrm{H}$ & 10 & 96 \\
\hline 11 & 4-tert-Butyl & $\mathrm{H}$ & 10 & 99 \\
\hline
\end{tabular}

a Reaction conditions: aryl bromide, $1.0 \mathrm{mmol}$; phenylboronic acid, 1.5 mmol; catalyst Pd@PAN-Ad-0.5, (13.7 mg, 0.075 mol\% Pd); $i$ - $\mathrm{PrOH} / \mathrm{H}_{2} \mathrm{O}, 2.0 \mathrm{~mL} ; \mathrm{K}_{2} \mathrm{CO}_{3}$, $(2.0 \mathrm{mmol}, 276.4 \mathrm{mg})$; temperature, $100{ }^{\circ} \mathrm{C}$; under argon.

bIsolated yield.

ing biphenyls in high yields with low Pd loading (Table 3, entries 1-11). Thus, the application scope of the developed catalyst systems is wide.

\subsection{Catalyst characterisation and discussion}

To investigate the relationship between catalyst performance and structure, the catalysts were characterised. First, TEM was used to observe the Pd particles in the support. The TEM image in Fig. 1(a) reveals that the Pd nanoparticles were distributed well in the support and has an average diameter 2-3 nm. The recycled Pd@PAN-Ad-0.5 catalyst after five runs was also characterised by TEM (Fig. 1(b)). The average diameter of these $\mathrm{Pd}$ nanoparticles was 4-5 nm. Although Pd@PAN-Ad-0.5 was only slightly deactivated after five reaction cycles, the Pd nanoparticles aggregated to form particles that were about $5 \mathrm{~nm}$ in diameter. Moreover, nitrogen sorption-desorption analysis was performed for the Pd@PAN-Ad-0.5 catalyst. Its Brunauer-Emmett-Teller specific surface area was about $155.76 \mathrm{~m}^{2} / \mathrm{g}$ with an average pore diameter of $5.5 \mathrm{~nm}$ (Fig. 2).

SEM images at $1.0 \mu \mathrm{m}$ and $2.0 \mu \mathrm{m}$ (Fig. 3) showed that the Pd@PAN-Ad-0.5 catalyst was irregular with particles intertwined with each other. The energy-dispersive X-ray (EDX) elemental spectra of the Pd@PAN-Ad-0.5 catalyst (Fig. 4) indi-

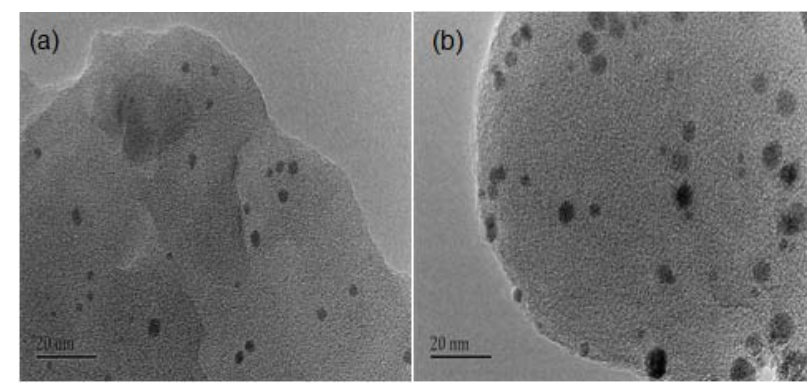

Fig. 1. TEM images of the fresh Pd@PAN-Ad- 0.5 catalyst (a) and recycled Pd@PAN-Ad-0.5 catalyst after five reaction runs (b). 

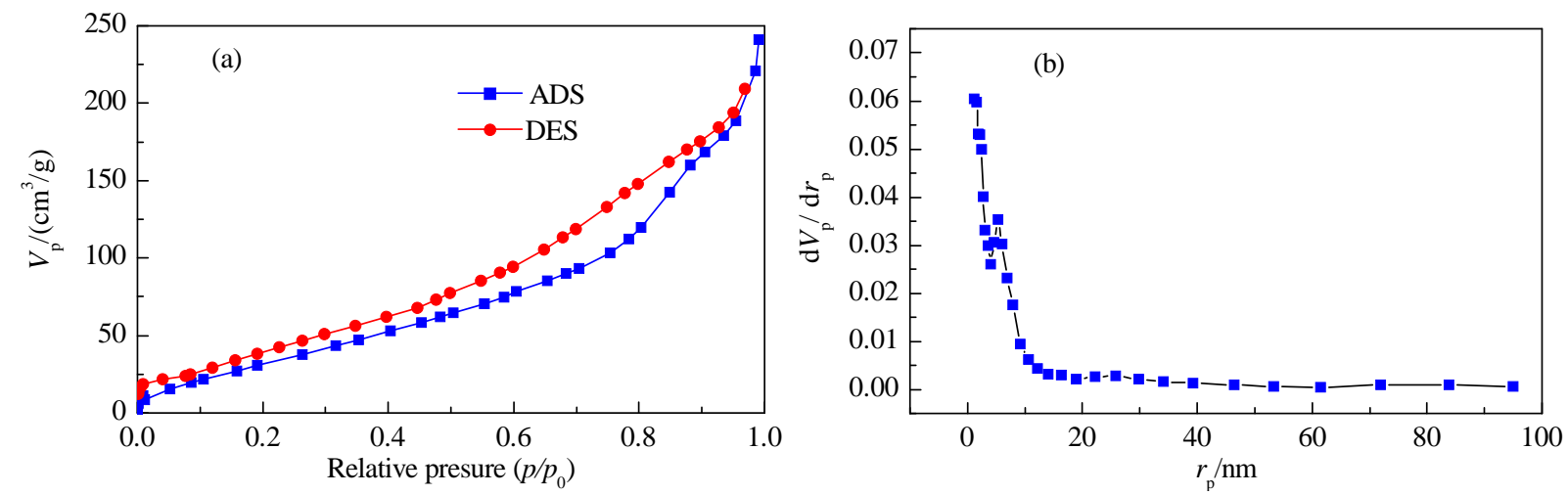

Fig. 2. Nitrogen adsorption-desorption isotherms (a) and the pore diameter distribution (b) of the Pd@PAN-Ad-0.5 catalyst.

cated that it contained C, N, P, Pd and I. Additionally, the FT-IR spectrum in Fig. 5 contained bands from 1500 to $500 \mathrm{~cm}^{-1}$ originating from phenyl rings, and between 3000 and 2750 $\mathrm{cm}^{-1}$ and at about $1500 \mathrm{~cm}^{-1}$ from adamantyl groups, which implies the diadamantylphosphine was anchored into the cross-linked PAN. The bands from 1500 to $1250 \mathrm{~cm}^{-1}$ are ascribed to $\mathrm{C} \equiv \mathrm{N}$ bonds. Moreover, TGA (Fig. 6) showed that the Pd@PAN-Ad- 0.5 catalyst lost only a small amount of mass between room temperature and $450{ }^{\circ} \mathrm{C}$, which should be related to the loss of water and solvent. The obvious mass loss from 450 to $760{ }^{\circ} \mathrm{C}$ was attributed to the decomposition of the catalyst. Therefore, the catalyst was stable up to $450{ }^{\circ} \mathrm{C}$ without evident mass loss. No characteristic diffraction peak of Pd was observed in the XRD pattern of the Pd@PAN-Ad- 0.5 catalyst (Fig. 7). This is because the Pd nanoparticles were small and the Pd content of the catalyst was low. XPS analysis of the Pd@PAN-Ad-0.5 catalyst revealed it contained two types of palladium species $\left(\mathrm{Pd}^{2+}\right.$ and $\left.\mathrm{Pd}^{0}\right)$ (Fig. 8(a)). The peaks at

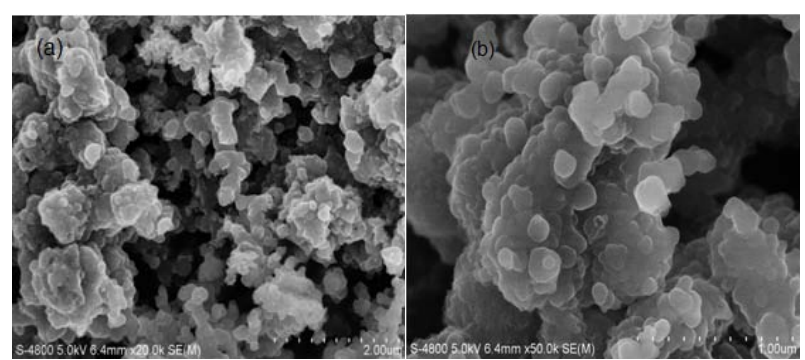

Fig. 3. SEM images of the Pd@PAN-Ad-0.5 catalyst.

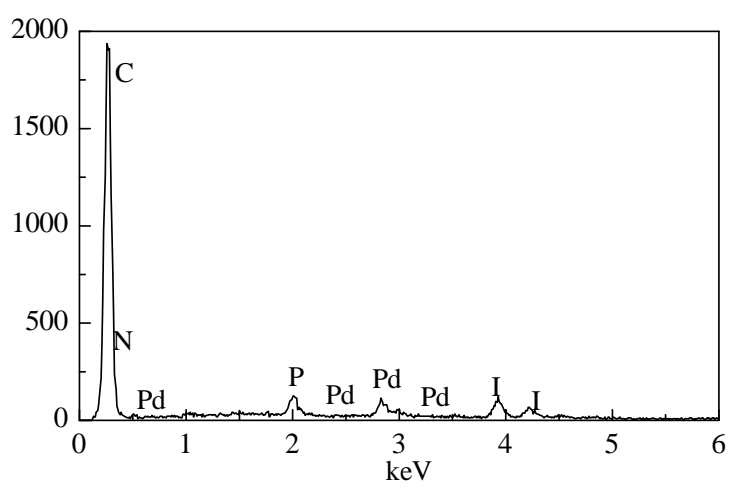

Fig. 4. EDX elemental analysis of the Pd@PAN-Ad- 0.5 catalyst. binding energies of $340.2 \mathrm{eV}\left(\mathrm{Pd} 3 d_{3 / 2}\right)$ and $335.5 \mathrm{eV}\left(\mathrm{Pd} 3 d_{5 / 2}\right)$ were assigned to $\mathrm{Pd}^{0}$ species, and those at $341.8\left(\mathrm{Pd} 3 d_{3 / 2}\right)$ and $337.1 \mathrm{eV}\left(\mathrm{Pd} 3 d_{5} / 2\right)$ corresponded to $\mathrm{Pd}^{2+}$ species (calibrated by $\mathrm{C} 1 s$ at $284.6 \mathrm{eV}$ ). Therefore, both $\mathrm{Pd}^{2+}$ and $\mathrm{Pd}^{0}$ are present in the Pd@PAN-Ad- 0.5 catalyst.

The Pd@PAN-Ad-0.5 catalyst was prepared firstly by Pd-catalysed C-P coupling to form the P ligand with aryl iodide. Then, the Pd-catalysed $\mathrm{C}-\mathrm{N}$ coupling reaction of aryl iodides with $p$-phenylenediamine was conducted with the Pd nanopar-

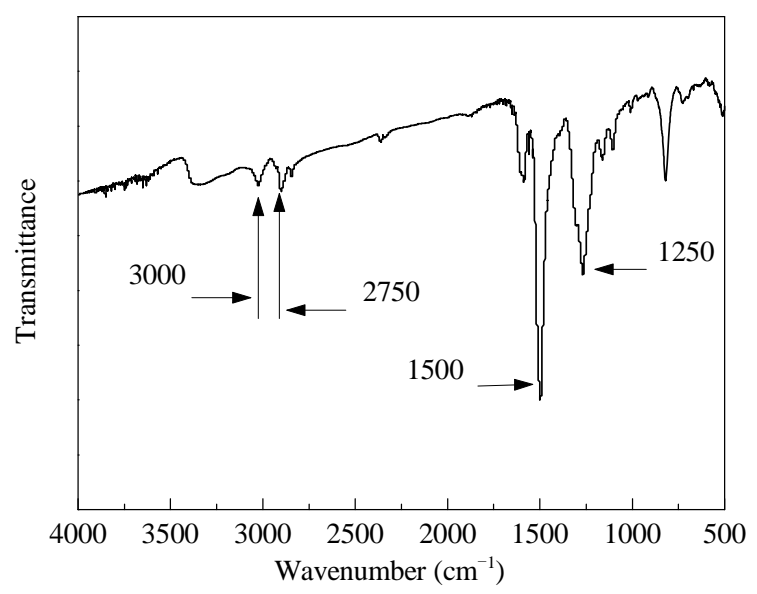

Fig. 5. FT-IR spectrum of the Pd@PAN-Ad-0.5 catalyst.

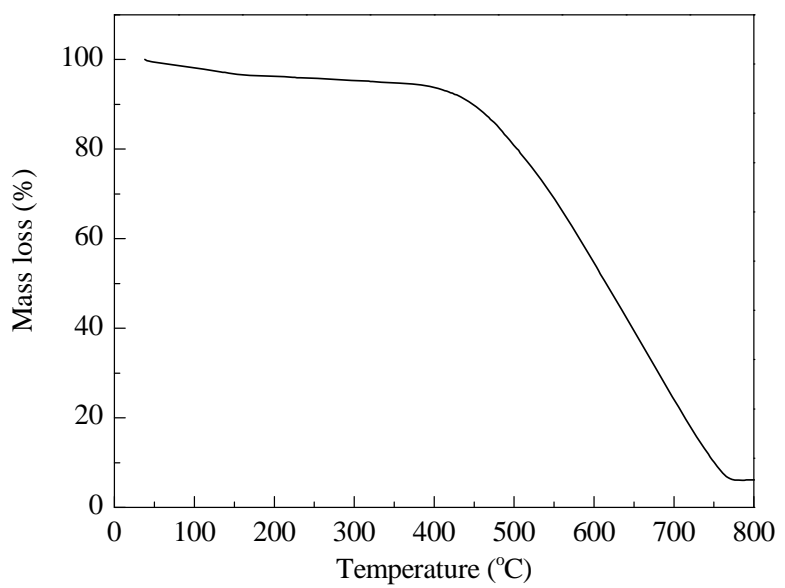

Fig. 6. TGA of the Pd@PAN-Ad- 0.5 catalyst. 


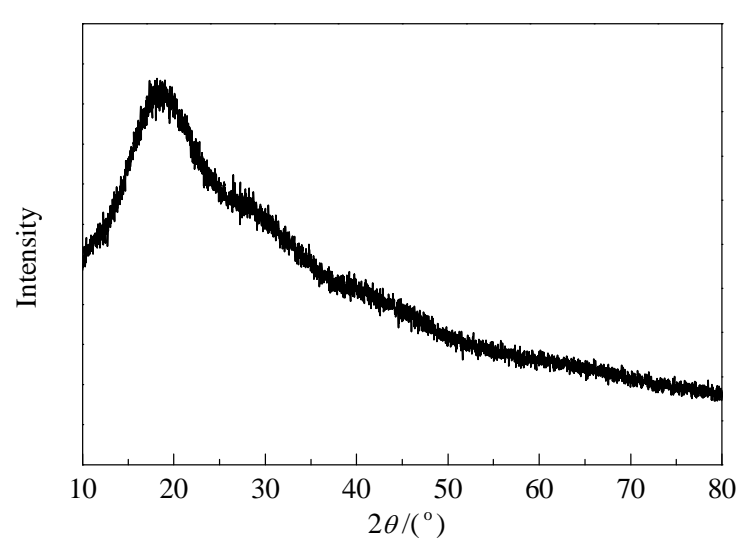

Fig. 7. XRD pattern of the Pd@PAN-Ad-0.5 catalyst.

ticles along with the P ligand. At the same time, Pd nanoparticles with the $\mathrm{P}$ ligand were immobilised in the cross-linked PAN to give the heterogeneous Pd@PAN-Ad-0.5 catalyst. Because PAN is a good support for Pd nanoparticles in Suzuki-Miyaura reactions, cross-linked PAN with a P ligand was designed and used in the developed Pd nanoparticle catalysts. The formation of cross-linked PAN with a P ligand not only improved the electron properties of the bulky ligand diadamantylphosphine, but also immobilised the active Pd nanoparticles. Thus, the Pd@PAN-Ad-0.5 catalyst is highly active and reusable in cross-coupling reactions.

\subsection{Application and reusability of the Pd@PAN-Ad-0.5 catalyst for the synthesis of 4'-chloro-2-nitro-1,1'-biphenyl}

To explore the industrial application of the Pd@PAN-Ad-0.5 catalyst, we investigated the Suzuki-Miyaura coupling reaction of 2-nitrochlorobenzene with 4-chloro-phenylboronic acid, because the corresponding product 4'-chloro-2-nitro-1,1'-biphenyl is an important pharmaceutical intermediate for the synthesis of boscalid (see Scheme 2). The intermediate was obtained in $96 \%$ yield. Moreover, the reusability of the Pd@PAN-Ad-0.5 catalyst in the Suzuki-Miyaura coupling reaction of 2-chlorobenzonitrile with 4-methylphenylboronic acid was investigated, as illustrated in Fig. 9. The Pd@PAN-Ad-0.5 catalyst could be reused at least five times without marked deactivation. The yield of target product

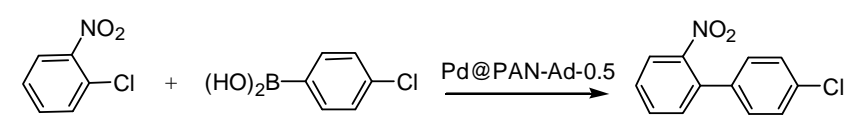

Scheme 2. Pd@PAN-Ad-0.5-catalysed Suzuki-Miyaura coupling of 2-nitrochlorobenzene and 4-chlorophenylboronic acid.

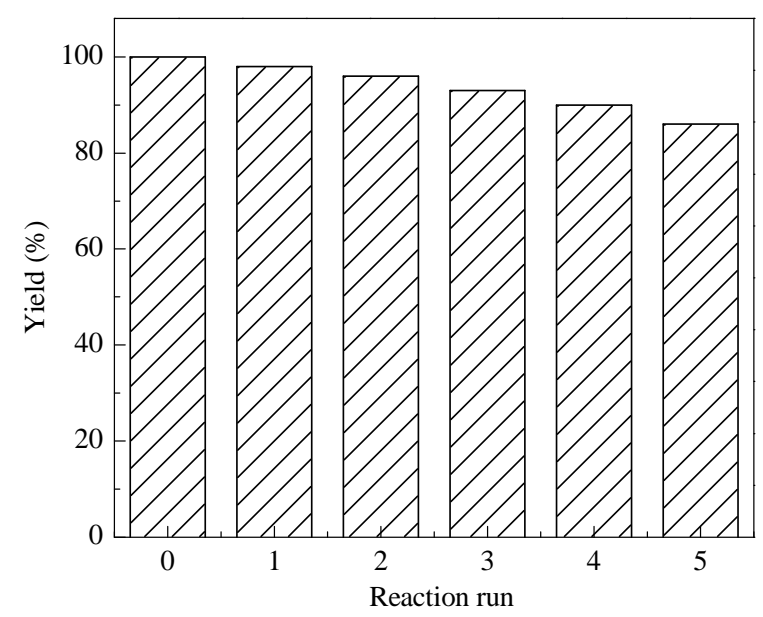

Fig. 9. The reusability of the Pd@PAN-Ad-0.5 catalyst in the Suzuki-Miyaura coupling of 2-chlorobenzonitrile with 4-methylphenylboronic acid.

was $86 \%$ after the fourth cycle. During the recycling process, the Pd content in the reaction solution was measured by ICP-AES. No Pd was detected in the solution (that is, Pd content was below the detection limit of 7 ppb), so the Pd@PAN-Ad-0.5 catalyst is clean.

\section{Conclusions}

We fabricated supported Pd catalysts on cross-linked PAN with a P ligand. The Pd catalysts showed high efficiency in the Suzuki-Miyaura reaction of aryl chlorides and bromides with phenylboronic acids. Moreover, functional groups, such as $\mathrm{CN}$, $\mathrm{MeO}, \mathrm{CHO}, \mathrm{MeCO}$ and $\mathrm{NO}_{2}$, were tolerated well, and the corresponding biphenyls were obtained in high yields. The Pd catalysts could be reused at least five times without evident deactivation. We believe that this kind of catalyst shows potential for the synthesis of biphenyl chemicals in the laboratory and industry.
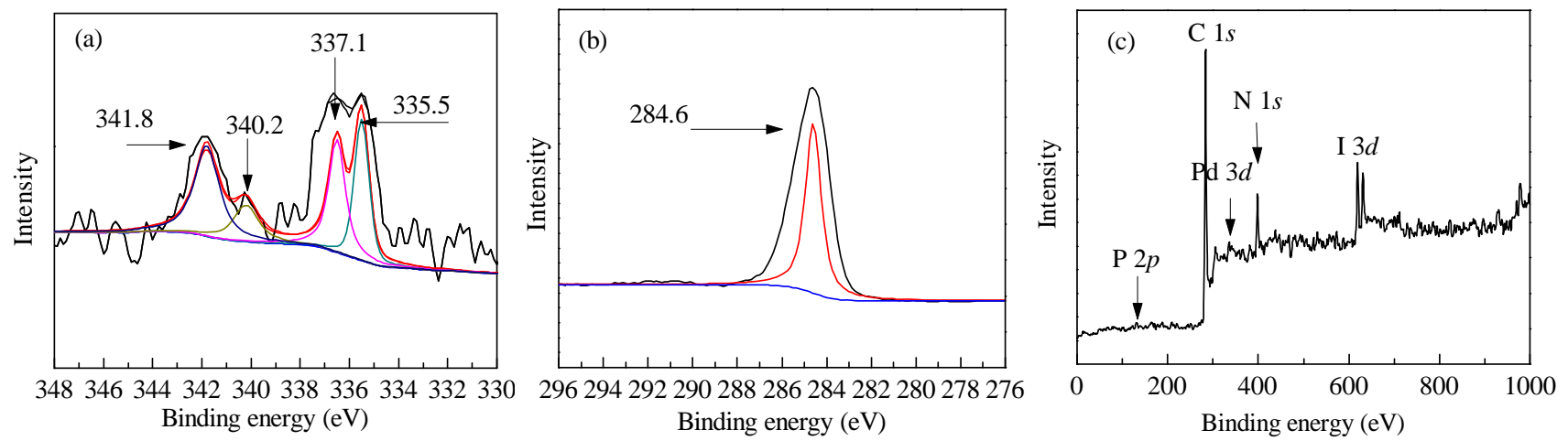

Fig. 8. XPS analysis of the Pd@PAN-Ad-0.5 catalyst. (a) Pd 3d; (b) C $1 s$; (c) Survey spectrum. 


\section{References}

[1] C. C. C. Johansson Seechurn, M. O. Kitching, T. J. Colacot, V. Snieckus, Angew. Chem. Int. Ed., 2012, 51, 5062-5085.

[2] A. J. J. Lennox, G. C. Lloyd-Jones, Chem. Soc. Rev., 2014, 43, 412-443.

[3] J. K. Wang, Y. X. Zong, X. C. Wang, Y. L. Hu, G. R. Yue, Y. Pan, Green Chem., 2016, 18, 967-973.

[4] G. D. Ding, W. T. Wang, T. Jiang, B. X. Han, Green Chem., 2013, 15, 3396-3403.

[5] A. Molnar, Chem. Rev., 2011, 111, 2251-2320.

[6] J. F. Hartwig, Nature, 2008, 455, 314-322.

[7] A. Fihri, M. Bouhrara, B. Nekoueishahraki, J. M. Basset, V. Polshettiwar, Chem. Soc. Rev., 2011, 40, 5181-5203.

[8] N. Miyaura, A. Suzuki, Chem. Rev., 1995, 95, 2457-2483.

[9] S. Paul, M.M. Islam, S.M. Islam, RSC Adv., 2015, 5, 42193-42221.

[10] P. Das, W. Linert, Coord. Chem. Rev., 2016, 311, 1-23.

[11] R. Garrido, P. S. Hernandez-Montes, A. Gordillo, P. Gomez-Sal, C. Lopez-Mardomingo, E. de Jesus, Organometallics, 2015, 34, 1855-1863.

[12] Y. Nakayama, N. Yokoyama, H. Nara, T. Kobayashi, M. Fujiwhara, Adv. Synth. Catal., 2015, 357, 2322-2330.

[13] N. Dehury, N. Maity, S.K. Tripathy, J. M. Basset, S. Patra, ACS Catal., 2016, 6, 5535-5540.

[14] L. C. Lee, J. He, J. Q. Yu, C. W. Jones, ACS Catal., 2016, 6, 5245-5250.

[15] S. Roy, H. Plenio, Adv. Synth.Catal., 2010, 352, 1014-1022.

[16] W. Q. Fu, Y. Feng, Z. X. Fang, Q. Chen, T. Tang, Q. Y. Yu, T. D. Tang, Chem. Commun., 2016, 52, 3115-3118.

[17] J. X. Yang, X. M. Tan, Y. Wang, X. H. Wang, J. Porous Mater., 2013, 20, 501-506.

[18] F. Wang, J. Mielby, F. H. Richter, G. H. Wang, G. Prieto, T. Kasama, C. Weidenthaler, H. J. Bongard, S. Kegnæs, A. Furstner, F. Schuth, Angew. Chem. Int. Ed., 2014, 53, 8645-8648.

[19] E. Rangel Rangel, E. M. Maya, F. Sánchez, J. G. de la Campa, M. Iglesias, Green Chem., 2015, 17, 466-473.
[20] T. L. Cui, W. Y. Ke, W. B. Zhang, H. H. Wang, X. H. Li, J. Chen, Angew. Chem. Int. Ed., 2016, 55, 9178-9182.

[21] Y. Kitamura, S. Sako, T. Udzu, A. Tsutsui, T. Maegawa, Y. Monguchi, H. Sajiki, Chem. Commun., 2007, 5069-5071.

[22] D. H. Lee, J. Y. Jung, M. J. Jin, Green Chem., 2010, 12, 2024-2029.

[23] J. W. Sun, Y. S. Fu, G. Y. He, X. Q. Sun, X. Wang, Appl. Catal. B, 2015, 165, 661-667.

[24] R. Sun, B. Liu, B. G. Li, S. Y. Jie, ChemCatChem, 2016, 8, 3261-3271.

[25] C. J. Welch, J. Albaneze-Walker, W. R. Leonard, M. Biba, J. DaSilva, D. Henderson, B. Laing, D. J. Mathre, S. Spencer, X. D. Bu, T. B. Wang, Org. Process Res. Dev., 2005, 9, 198-205.

[26] Z. Wang, Y. Yu, Y. X. Zhang, S. Z. Li, H. Qian, Z. Y. Lin, Green Chem., 2015, 17, 413-420.

[27] T. Fujihara, T. Yoshikawa, M. Satou, H. Ohta, J. Terao, Y. Tsuji, Chem. Commun., 2015, 51, 17382-17385.

[28] A. K. Rathi, M. B. Gawande, J. Pechousek, J. Tucek, C. Aparicio, M. Petr, O. Tomanec, R. Krikavova, Z. Travnicek, R. S. Varma, R. Zboril, Green Chem., 2016, 18, 2363-2373.

[29] Z. M. Dong, Z. B. Ye, Adv. Synth. Catal., 2014, 356, 3401-3414.

[30] A. Molnar, Chem. Rev., 2011, 111, 2251-2320.

[31] T. Iwai, R. Tanaka, T. Harada, M. Sawamura, Chem. Eur. J., 2014, 20, 1057-1065.

[32] D. Martinez-Solorio, B. Melillo, L. Sanchez, Y. Liang, E. Lam, K. N. Houk, A. B. Smith, J. Am. Chem. Soc., 2016, 138, 1836-1839.

[33] Y. B. Zhou, C. Y. Li, M. Li, Y. J. Ding, Z. P. Zhan, Adv. Synth. Catal., 2015, 357, 2503-2508.

[34] D. Sahu, A. R. Silva, P. Das, Catal. Commun., 2016, 86, 32-35.

[35] T. J. Hu, T. Schulz, C. Torborg, X. R. Chen, J. Wang, M. Beller, J. Huang, Chem. Commun., 2009, 7330-7332.

[36] J. L. Zhang, X. R. Chen, T. J. Hu, Y. Zhang, K. L. Xu, Y. P. Yu, J. Huang, Catal. Lett., 2010, 139, 56-60.

[37] T. J. Hu, X. R. Chen, J. Wang, J. Huang, ChemCatChem, 2011, 3, 661-665.

[38] Y. P. Yu, T. J. Hu, X. R. Chen, K. L. Xu, J. L. Zhang, J. Huang, Chem.

\section{Graphical Abstract}

Chin. J. Catal., 2017, 38: 589-596 doi: 10.1016/S1872-2067(17)62772-4

Palladium nanoparticles in cross-linked polyaniline as highly efficient catalysts for Suzuki-Miyaura reactions

Haipeng Fan, Zhengliang Qi, Dejun Sui, Fei Mao, Rizhi Chen, Jun Huang*

Nanjing Tech University

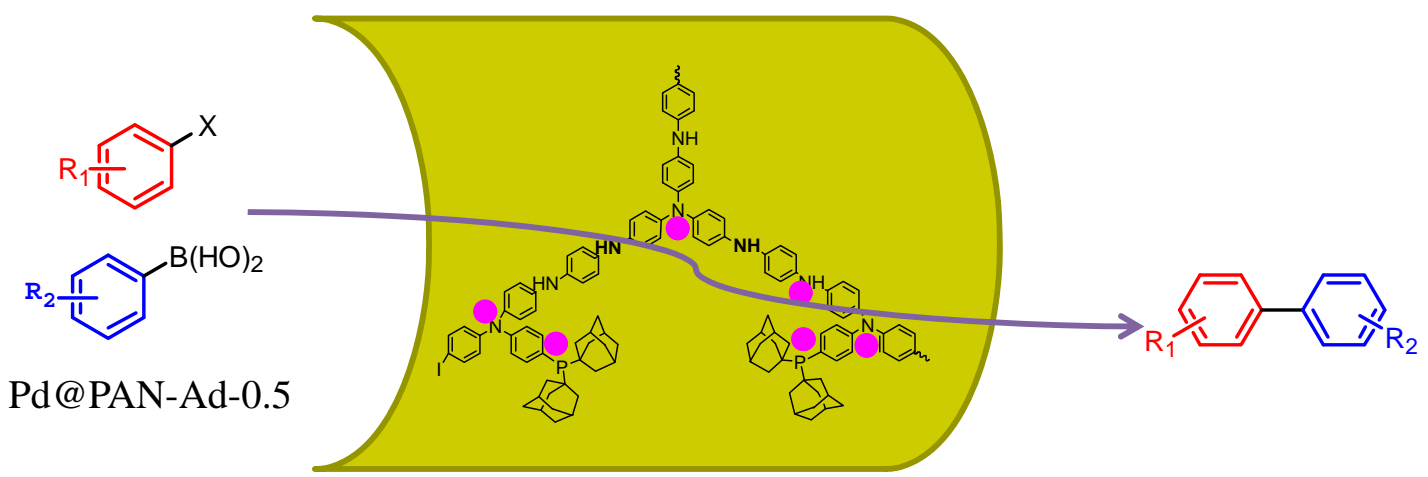

Palladium nanoparticles supported on cross-linked polyaniline with bulky phosphorus-based ligands were developed as highly efficient catalysts for the Suzuki-Miyaura reaction of aryl chlorides and bromides with phenylboronic acids. 
Commun., 2011, 47, 3592-3594.

[39] Y. Li, F. Mao, T. Chen, Z. C. Zhou, Y. Wang, J. Huang, Adv. Synth. Catal., 2015, 357, 2827-2832.

[40] L. F. Geng, Y. Li, Z. L. Qi, H. P. Fan, Z. C. Zhou, R. Z. Chen, Y. Wang, J. Huang, Catal. Commun., 2016, 82, 24-28.

[41] B. J. Gallon, R. W. Kojima, R. B. Kaner, P. L. Diaconescu, Angew. Chem. Int. Ed., 2007, 46, 7251-7254.
[42] B. M. Choudary, M. Roy, S. Roy, M. L. Kantam, B. Sreedhar, K. V. Kumar, Adv. Synth. Catal., 2006, 348, 1734-1742.

[43] S. Dutt, R. Kumar, P. F. Siril, RSC Adv., 2015, 5, 33786-33791.

[44] H. A. Patel, A. L. Patel, A. V. Bedekar, New J. Chem., 2016, 40, 8935-8945.

[45] C. A. Wheaton, J. P. J. Bow, M. Stradiotto, Organmetallics, 2013, $32,6148-6161$.

\title{
钯纳米颗粒负载在聚苯胺材料上制得催化Suzuki-Miyaura偶联反应的高效催化剂
}

\author{
㚞海鹏, 祁正亮, 随德君, 毛飞, 陈日志, 黄 军* \\ 南京工业大学化工学院, 江苏南京210009
}

\begin{abstract}
摘要: 在最近的几十年里, 金属钯催化的Suzuki-Miyaura偶联反应已经得到了越来越多的关注, 被广泛应用于药物、天然产 物以及新材料的合成. 与此同时均相催化剂发展迅速, 高效的配体和大量的设计被用于Suzuki-Miyaura偶联反应中, 但是 钯催化剂的配体通常很昂贵和难以合成, 因此钯催化剂系统的回收是非常有价值的, 不仅是经济上的原因, 同时也避免了 产品的污染, 所以发展非均相催化剂是必要的. 近年来, 研究学者们致力于设计非均相的钯催化剂, 如将钯纳米颗粒负载 到金属有机骨架、介孔分子篮以及活性炭等多种材料上得到的非均相钯催化剂并应用于Suzuki-Miyaura偶联反应中. 我们 主要介绍了钯纳米颗粒被负载在含磷配体的交联的聚苯胺材料上制得负载的钯催化剂, 首先通过钯催化的三(4-碘苯基)胺 与金刚烷基膦的 $\mathrm{C}-\mathrm{P}$ 偶联, 再由钯催化三(4-碘苯基)胺与对苯二胺的 $\mathrm{C}-\mathrm{N}$ 偶联, 进而得到钯纳米颗粒负载在含金刚烷基膦的 聚苯胺材料上的催化剂Pd@PAN-Ad-0.5 (钯含量为 $0.58 \mathrm{wt} \%$ ), 同时我们对催化剂进行了一些表征, 如TEM, SEM, XRD, EDX, XPS, FT-IR, ICP等.

通过TEM分析, 我们发现钯纳米颗粒在聚合物表面分布均匀, 并且金属钯的平均粒径为2-3 nm; EDX检测显示催化剂 含有 C, N, P, Pd, I 元素, 说明钯负载到含金刚烷基膦的聚苯胺材料上的催化剂Pd@PAN-Ad-0.5已经形成, 并被用于 Suzuki-Miyaura偶联反应. 我们对反应体系中的各种影响因素进行了优化, 包括溶剂、碱、反应时间、催化剂加入量以及 不同的催化剂的优化, 最终确定了最佳反应条件; 对于带有不同取代基(如腈基、甲氧基、酫基、酮基以及硝基)的氯代芳 烃和溴代芳烃与苯硼酸的Suzuki-Miyaura反应, 以较少的催化剂使用量 $(0.075 \mathrm{~mol} \% \mathrm{Pd})$ 就能获得较高的相应的联苯产物收 率. 此外, 催化剂Pd@PAN-Ad-0.5在偶联反应中具有较高的反应活性的同时, 还具有较好的回收使用能力(至少能够回收使 用5次),循环使用4次以后还具有较高的催化活性. 为了探索催化剂Pd@PAN-Ad-0.5在工业上的应用, 由于 4'-氯-2-硝基-1,1'联苯是合成啶酰菌胺药物的重要中间体, 因此我们使用催化剂Pd@PAN-Ad-0.5催化2-硝基氯苯与4-氯苯硼酸的偶联反应, 目标产物4'-氯-2-硝基-1,1'-联苯的收率高达 $96 \%$. 我们相信这类催化剂应用于实验室或工业上合成联苯化学品具有较大的 潜力.
\end{abstract}

关键词: 钯; 多相催化剂; 聚苯胺; Suzuki-Miyaura偶联反应; 联苯

收稿日期: 2016-11-29. 接受日期: 2016-12-27. 出版日期: 2017-03-05.

*通讯联系人. 电话: (025)83172261; 传真(025)83172261; 电子信箱: junhuang@njtech.edu.cn

基金来源：国家自然科学基金(21676140); 材料化学工程国家重点实验室基金(ZK201402); 江苏高校优势学科建设工程(PAPD). 本文的英文电子版由Elsevier出版社在ScienceDirect上出版(http://www.sciencedirect.com/science/journal/18722067). 